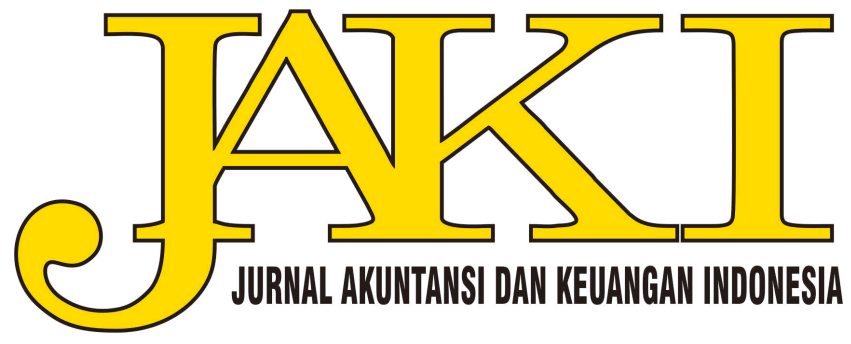

Volume 18

Issue 1 Volume 18, Issue 1, 2021

Article 2

7-31-2021

\title{
THE IMPACT OF KEY AUDIT MATTERS DISCLOSURE ON COMMUNICATIVE VALUE OF THE AUDITOR'S REPORT: A SYSTEMATIC LITERATURE REVIEW
}

Budhi Setiya Yoga

Center for Finance Professions Supervisory

Agung Dinarjito

Polytechnic of State Finance STAN

Follow this and additional works at: https://scholarhub.ui.ac.id/jaki

Part of the Accounting Commons, Corporate Finance Commons, Finance and Financial Management Commons, and the Taxation Commons

Recommended Citation

Yoga, Budhi Setiya and Dinarjito, Agung (2021) "THE IMPACT OF KEY AUDIT MATTERS DISCLOSURE ON COMMUNICATIVE VALUE OF THE AUDITOR'S REPORT: A SYSTEMATIC LITERATURE REVIEW," Jurnal Akuntansi dan Keuangan Indonesia: Vol. 18: Iss. 1, Article 2.

DOI: 10.21002/jaki.2021.02

Available at: https://scholarhub.ui.ac.id/jaki/vol18/iss1/2

This Article is brought to you for free and open access by the Faculty of Economics \& Business at UI Scholars Hub. It has been accepted for inclusion in Jurnal Akuntansi dan Keuangan Indonesia by an authorized editor of UI Scholars Hub. 
Jurnal Akuntansi dan Keuangan Indonesia

Volume 18 Issue 1, June 2021

\title{
THE IMPACT OF KEY AUDIT MATTERS DISCLOSURE ON COMMUNICATIVE VALUE OF THE AUDITOR'S REPORT: A SYSTEMATIC LITERATURE REVIEW
}

\author{
Budhi Setiya Yoga \\ Center for Finance Professions Supervisory \\ bsyoga1@gmail.com \\ Agung Dinarjito \\ Polytechnic of State Finance STAN \\ agung.dinarjito@pknstan.ac.id
}

\begin{abstract}
This research aims to discuss whether the disclosure of key audit matters (KAM) increases the communicative value of the auditor's report. It also examines factors that need to be considered related to KAM disclosure. It is carried out in connection with the issuance of the Exposure Draft of Indonesia Audit Standard (AS) 701 on "Pengomunikasian Hal Audit Utama dalam Laporan Auditor Independen" which was adopted from the International Standard on Auditing 701. In Indonesia, no research was found yet related to this topic. By conducting a systematic literature review of the latest articles from 2012 to 2021, this study found that KAM disclosure increases the communicative value of the auditor's report, which is useful for report users in their decision-making. This study also informed specific areas that were often disclosed as KAM and provided information related to the factors that can decrease the communicative value of KAM disclosure. The results support the plan of AS 701 implementation in Indonesia because it will increase the communicative value of the auditor's report. This study will be of interest to auditors in preparing the implementation of AS 701, report users in understanding KAM disclosure, and regulators as initial information regarding KAM disclosure to support their duties when AS 701 has been effectively implemented in Indonesia.
\end{abstract}

Keywords: key audit matters, ISA 701, auditor's report, communicative value, report users

\begin{abstract}
Abstrak
Penelitian ini bertujuan untuk membahas apakah pengungkapan key audit matters (KAM) meningkatkan nilai komunikatif laporan auditor dan untuk meneliti hal-hal yang perlu diperhatikan sehubungan dengan pengungkapan KAM. Penelitian dilakukan sehubungan dengan terbitnya Draf Eksposur Standar Audit (SA) 701 tentang Pengomunikasian Hal Audit Utama dalam Laporan Auditor Independen yang mengadopsi International Standard on Auditing 701. Di Indonesia, Peneliti belum menemukan penelitian terdahulu terkait topik ini. Dengan melakukan tinjauan literatur sistematis (systematic literature review) atas artikel terkini sejak 2012 sampai 2021, penelitian ini menemukan bahwa pengungkapan KAM meningkatkan nilai komunikatif laporan auditor yang berguna bagi pengguna laporan dalam pengambilan keputusannya. Selain itu, penelitian ini menginformasikan area-area spesifik yang penting untuk diungkapkan sebagai KAM. Penelitian ini juga memberikan informasi terkait faktor-faktor yang dapat menurunkan nilai komunikatif pengungkapan KAM. Hasil dari penelitian ini mendukung rencana implementasi SA 701 di Indonesia sebab hal tersebut akan meningkatkan nilai komunikatif dari laporan auditor. Penelitian ini juga bermanfaat bagi auditor dalam mempersiapkan implementasi SA 701, bagi pengguna laporan dalam
\end{abstract}


memahami pengungkapan KAM, dan bagi regulator sebagai informasi awal terkait pengungkapan KAM untuk mendukung pelaksanaan tugasnya ketika SA 701 telah efektif diimplementasikan di Indonesia.

\section{Kata kunci: key audit matters, ISA 701, laporan auditor, nilai komunikatif, pengguna laporan}

\section{INTRODUCTION}

Key audit matters (KAM) are those matters that, in the auditor's professional judgment, are the most significant areas of the audited financial statement of the current period (IAASB 2015a). KAM was initiated by the International Auditing and Assurance Standard Board (IAASB) as the international audit standard-setting board, which aims at increasing transparency of audited financial statements (IAASB $2015 b$ ). It is the IAASB's response to the users of audited financial statements that encourages auditors to present the report in a more detailed manner. Thus, the auditor should provide additional relevant information for users based on the audit that has been carried out (IAASB 2013). One of the manifestations of this initiative is the issuance of the International Standard on Auditing (ISA) 701 on Communicating Key Audit Matters in the Independent Auditor's Report. It applies for financial statements of the financial year period that ends on or after December 15 2016, for listed entities (IAASB 2015b).

In ISA 701, the IAASB (2015b) expressed that the purpose of KAM disclosure is to increase the communicative value of the auditor's report for users. It is achieved by providing greater transparency regarding the audits that have been carried out. The IAASB (2012) declared that the communicative value of the auditor's report would be achieved when the auditor's report can provide clearer information needed by the users. Hence, it can minimize the information gap, i.e. the discrepancy between user's expectations about what should be available to help them make investment and fiduciary decisions and what is actually available to them through the entity's audited financial statements, auditor's reports, and other public information sources (IAASB 2012). The IAASB (2012) states that the users of the auditor's report are mainly investors, analysts, lenders, regulators, and so forth.

Some countries have adopted ISA 701 in their audit standards since the 2016 financial year, including Australia, New Zealand, the United Kingdom, most European countries (Kend and Nguyen 2020), and China ( $\mathrm{Wu}$ et al. 2019). Meanwhile, ASEAN countries that have adopted ISA 701 in their audit standards for audits of the 2016 financial year include Malaysia (Min and Kee 2019), Philippines (AASC 2017), Thailand (Kitiwong and Sarapaivanich 2020), and Singapore (ACRA et al. 2017). Indonesia has not yet effectively adopted and implemented ISA 701. However, on January 27 2021, according to Letter Number: 0595/I/IntIAPI/2021, the Professional Standards Board of Indonesian Public Accountants I (DSPAP I) - the Indonesian Institute of Certified Public Accountants (IAPI) has disseminated the Exposure Draft (ED) of Audit Standard (AS) 701 on "Pengomunikasian Hal Audit Utama dalam Laporan Auditor Independen" to IAPI members and the public to welcome any feedback (IAPI 2021). The ED AS 701 is the adoption of ISA 701 on Communicating Key Audit Matters in the Inde-pendent Auditor's Report issued by the IAASB (IAPI 2021). The ED proposed AS 701 to be implemented effectively for audits of financial statements that financial year starting on or after January 1 2022, for listed entities.

In ED AS 701, the term key audit matters were adopted as "hal audit utama" (IAPI 2021). Paragraph 8 of ED AS 701 mentions that "hal audit utama" is "... those matters that, in the auditor's professional 
judgment, are the most significant areas in the audit of the current period's financial statements. Key audit matters are selected from those that are communicated with those charged with governance." Moreover, paragraph 2 of ED AS 701 declares that the objective of communicating the key audit matters is "...to increase the communicative value of the auditor's report by providing greater transparency over the audits that have been performed." The issuance of ED AS 701 provides new hope for users of audited financial statements and auditor's reports in Indonesia because it can increase information transparency and reduce the information gap that will be useful in the decision-making of report users, as desired in the initial goal of ISA 701.

However, previous studies found different results regarding whether disclosure of KAM increases the communicative value of the auditor's report or not. Several studies stated that KAM disclosure did not affect the communicative value of auditor's reports, as exemplified by Segal (2019) and Boolaky and Quick (2016). Based on interviews with auditors in South Africa, Segal (2019) found that KAM disclosure did not increase the communicative value of the information disclosed in the auditor's report because the audit committee and client directors did not pay special attention to KAM. The reason is that report users need to acquire high technical ability /knowledge to understand KAM disclosure. In addition, based on a case study of bank directors in Germany, Boolaky and Quick (2016) also found that KAM disclosure did not increase the communicative value of the auditor's report. In that case, KAM disclosure was considered to have no influence when bank directors decide whether or not to grant credit to corporations.

Meanwhile, several other studies found that the disclosure of KAM increases the communicative value of the auditor's report (Junior and Galdi 2019; Kitiwong and Sarapaivanich 2020). Based on an event study of companies listed on the
Brazilian Stock Exchange, Junior and Galdi (2019) found that KAM disclosure provides relevant information for investors in the capital market in investment decision analysis. Further, Kitiwong and Sarapaivanich (2020) conducted a logistic regression of company data in Thailand two years before and two years after the implementation of KAM standard. They found that the disclosure of KAM makes the auditor's report more informative, especially acquisition-related disclosures, which indicates a restatement of financial statements in the next periods.

Because previous studies showed different results, we conducted a study using a systematic literature review method by analyzing the latest relevant articles from 2012 to 2021 (April 14 2021) to determine the impact of the disclosure of key audit matters on the communicative value of the auditor's report comprehensively. To the best of our knowledge, based on the search on Google Scholar and Web of Science, there has been no research in Indonesia related to this topic. Thus, this research is expected to serve as the first research discussing key audit matters or "hal audit utama" in Indonesia. Therefore, it contributes to becoming the forerunner of further research in Indonesia. Specifically, this study aims to answer two research questions, namely:

a. Does the disclosure of key audit matters increase the communicative value of the auditor's report?

b. What considerations should be taken into account related to disclosure of key audit matters?.

As Snyder (2019) stated, the systematic literature review method is an appropriate method to obtain an overview of the particular topic under investigation. It can provide evidence of the impact of a matter to inform policymakers and incharged stakeholders. Therefore, the results of this study are expected to provide scientific evidence on the impact of key audit matters disclosure on the communicative value of the auditor's report. In addition, this study can highlight issues that 
need to be paid attention to in connection with the disclosure of KAM.

On top of that, the results of this study are expected to provide information on whether the goal of KAM disclosure to increase the communicative value of the auditor's report has been achieved or not. Hence, it can provide additional information on the benefits of KAM disclosure. Furthermore, the result can give additional information that supports the implementation of AS 701 in Indonesia. This study is also expected to be useful for auditors, report users, and regulators for preparing the implementation of AS 701 in Indonesia later.

This research is presented with the following structure. After the introduction, the research methodology is elaborated to inform readers how we screen, identify, and interpret the articles. Then, the results are presented and discussed by focusing on key features and their relevancy with earlier studies. Following that, the paper provides brief conclusions along with the study's contributions, limitations, and suggestions for further research.

\section{METHODOLOGY}

This study filtered articles through several stages, from determining search terms, the database to be used for searching, and criteria for selecting papers that would be excluded/included (Snyder 2019). In the first stage, we determined the search terms/keywords being searched on the specified database. According to Snyder (2019), search terms should be based on words and concepts that are directly related to the research question. Therefore, to find articles relevant to the research questions, we employed the following keyword: "key audit matters" and "communicative value". The search databases used were Google Scholar and Web of Science. Google Scholar was used due to its capacity to identify highly-cited documents effectively (MartinMartin et al. 2017). Furthermore, MartinMartin et al. (2017) stated that it has a broad search scope without limiting the type and source of search results documents. Moreover, Google Scholar can also be used as the first choice and is sufficient to serve as the sole source for conducting systematic review (Jean-Francois et al. 2013). Ginieis et al. (2012) also use Google Scholar, which is open access, as one of the databases in his systematic literature review research.

This research decided to include only articles that were published between 2012 and 2020. 2012 was determined as the limitation because in that year, the IAASB began to disseminate the Invitation to Comment: Improving Auditor's Report in which the term key audit matters" was introduced in June 2012 to solicit responses from stakeholders. Furthermore, in 2013 the IAASB has disseminated the Exposure Draft of ISA 701 on Communicating Key Audit Matters in the Independent Auditor's Report. Therefore, research related to key audit matters may have been started in 2012. While the determination of the end of 2020 is intended to obtain the latest relevant articles. Based on the search criteria, 197 articles were obtained (October 30, 2020). The search pairing KAM with communicative value in Indonesianlanguage keywords i.e.: "key audit matters" and "nilai komunikatif"; "hal audit utama" and "nilai komunikatif"; or "hal audit utama" and "communicative value" did not generate any articles (October 30, 2020). It indicated that there was no research yet conducted in the Indonesian language or Indonesia-related topic.

In the second stage, having collected 197 articles, screening was conducted according to the article's title and/or abstract. The purpose was to determine the English-language articles that discussed key audit matters and/or communicative value so that they did not only contain the phrase "key audit matters" and/or " communicative value" in the article and/or reference section. Based on these criteria, this stage generates 91 articles.

In the last stage, we conducted a thorough and more detailed analysis of the 


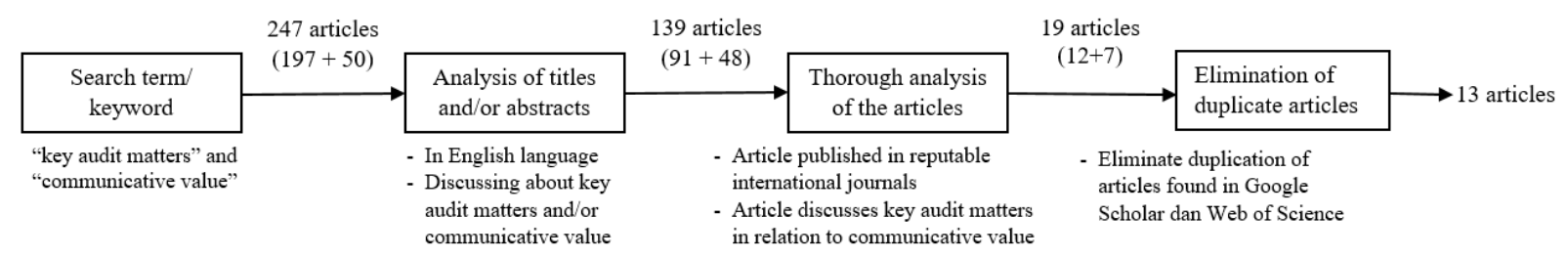

Figure 1. Articles Selection Process

entire article to find out the type of article and the focus of the article's discussion. We determined that only articles published in reputable international journals indexed by Scopus would proceed. Additionally, the articles must focus on discussing key audit matters in relation to the communicative value to be included as final articles for review. Articles in the form of theses, books, dissertations, working papers, comment letters, and other articles that are not published in reputable international journals indexed by Scopus were excluded as review source documents. A rigorous screening method was employed in determining the final articles for review to ensure the quality of the source documents reviewed (Tranfield et al. 2003).

Based on the final screening, 38 articles were published in reputable international journals. However, there were 20 articles whose focus was not on key audit matters in relation to communicative value. In addition, six articles were not published in Scopus-indexed journals. Therefore, as the final result, we obtained 12 Englishlanguage articles that focused on the discussion of key audit matters in relation to communicative value. All these articles were published in international journals indexed by Scopus.

Furthermore, during the review process of publishing this study in this journal, we updated the reviewed articles by extending the end year to 2021 (April 11, 2021) by searching on the Web of Science database. In this search, we obtained 50 articles. 48 out of 50 articles were in English and discussed key audit matters and /or communicative value. Among those, 40 articles were published in international journals. However, 33 articles did not discuss KAM in relation to communicative value. As a result, we ontained seven articles that were published in reputable international journals discussing KAM in relation to communicative value. Of the seven articles, six articles were obtained in a previous search using Google Sholar on October 30, 2020. From this process, one new article was acquired for review from the Web of Science, namely Coram and Wang (2020).

Thus, 13 articles were obtained using the Google Scholar and Web of Science databases. This number was deemed sufficient because they were obtained through a series of detailed procedures that were presented transparently. Thus, articles that were really relevant to the research questions were obtained (Snyder 2019). Besides, other research that used systematic literature review research was documented to involve relatively the same number of articles, such as Sanchis et al. (2014) involving ten articles and Browning and Rigolon (2019) using 13 articles. Furthermore, the list of these 13 articles was sorted by year of publication and by researcher(s) name alphabetically, as provided in Table 1 . The article screening process is shown in Figure 1.

In analyzing selected articles, we identified the research methodology, research results concerning the research questions, as well as the main limitations of the study in producing research conclusions. The determination of the analytical method was carried out following the objectives of this study to answer the research questions (Snyder 2019). Furthermore, all the research results were summarized to answer the research questions. In conducting the analysis, we also identified and 
Table 1.

List of Selected Articles to Review

\begin{tabular}{|c|c|c|c|c|}
\hline No & Article Title & Researchers & Journal Name & $\begin{array}{l}\text { Journal } \\
\text { Ranking }\end{array}$ \\
\hline 1. & $\begin{array}{l}\text { Enhancing the auditor's report: To what extent } \\
\text { is there support for the IAASB's proposed } \\
\text { changes? }\end{array}$ & $\begin{array}{l}\text { Simnet and Huggins } \\
\text { (2014) }\end{array}$ & Accounting Horizons & $\mathrm{Q} 1$ \\
\hline 2. & $\begin{array}{l}\text { Addressing information needs to reduce the } \\
\text { audit expectation gap: Evidence from dutch } \\
\text { bankers, audited companies, and auditors }\end{array}$ & Litjens et al. (2015) & $\begin{array}{l}\text { International Journal of } \\
\text { Auditing }\end{array}$ & Q2 \\
\hline 3. & $\begin{array}{l}\text { Does recent academic research support } \\
\text { changes to audit reporting standards? }\end{array}$ & Bedard et al. (2016) & Accounting Horizons & Q1 \\
\hline 4. & $\begin{array}{l}\text { Bank directors' perceptions of expanded } \\
\text { auditor's reports }\end{array}$ & $\begin{array}{l}\text { Boolaky and Quick } \\
\text { (2016) }\end{array}$ & $\begin{array}{l}\text { International Journal of } \\
\text { Auditing }\end{array}$ & Q2 \\
\hline 5. & $\begin{array}{l}\text { The changing face of the auditor's report: } \\
\text { Implications for suppliers and users of } \\
\text { financial statements }\end{array}$ & Prasad and Chand (2017) & $\begin{array}{l}\text { Australian Accounting } \\
\text { Review }\end{array}$ & Q3 \\
\hline 6. & $\begin{array}{l}\text { The informational relevance of key audit } \\
\text { matters }\end{array}$ & Junior and Galdi (2019) & $\begin{array}{l}\text { Revista Contabilidade E } \\
\text { Financas }\end{array}$ & Q4 \\
\hline 7. & $\begin{array}{l}\text { Bright lines vs blurred lines: When do critical } \\
\text { audit matters influence investors' perceptions } \\
\text { of management's reporting credibility? }\end{array}$ & Ozlanski (2019) & Advances in Accounting & Q3 \\
\hline 8. & Key audit matters: Insight from audit experts & Segal (2019) & $\begin{array}{l}\text { Meditari Accountancy } \\
\text { Research }\end{array}$ & Q2 \\
\hline 9. & $\begin{array}{l}\text { The impact of key audit matter (KAM) } \\
\text { disclosure in audit reports on stakeholders' } \\
\text { reactions: A literature review }\end{array}$ & Velte and Issa (2019) & $\begin{array}{l}\text { Problems and } \\
\text { Perspectives in } \\
\text { Management }\end{array}$ & Q3 \\
\hline 10. & $\begin{array}{l}\text { The effect of disclosing key audit matters and } \\
\text { accounting standard precision on the audit } \\
\text { expectation gap }\end{array}$ & Coram and Wang (2020) & $\begin{array}{l}\text { International Journal of } \\
\text { Auditing }\end{array}$ & Q2 \\
\hline 11. & $\begin{array}{l}\text { Consequences of the implementation of } \\
\text { expanded audit reports with key audit matters } \\
\text { (KAMs) on audit quality }\end{array}$ & $\begin{array}{l}\text { Kitiwong and } \\
\text { Sarapaivanich (2020) }\end{array}$ & $\begin{array}{l}\text { Managerial Auditing } \\
\text { Journal }\end{array}$ & Q2 \\
\hline 12. & $\begin{array}{l}\text { The effects of key audit matters on the } \\
\text { auditor's report's communicative value: } \\
\text { Experimental evidence from investment } \\
\text { professionals and non-professional investors }\end{array}$ & Kohler et al. (2020) & Accounting in Europe & Q3 \\
\hline 13. & When do investors value key audit matters? & Moroney et al. (2020) & $\begin{array}{l}\text { European Accounting } \\
\text { Review }\end{array}$ & Q1 \\
\hline
\end{tabular}

analyzed whether an article has accommodated the limitations of other/ previous studies. By doing those processes, a comprehensive understanding of the research results can be obtained in all reviewed articles.

\section{RESULT AND ANALYSIS}

Thirteen articles have passed a screening process, as explained in the methodology section. The list of selected article titles, researcher(s) name and year of publication, name of journal publishers, and ranking of the journals is presented in Table 1.

To answer the research questions, information in each article was analyzed, covering the research method used, the main results/findings, the items whether the research found that disclosure of KAM increased the communicative value or not, and the main limitations of the articles reviewed. A summary of that information is contained in Table 2. Further discussion is conducted to answer the research questions. 
Table 2.

Articles that Analyze the Impact of Key Audit Matters Disclosure on the Communicative Value of Auditor's Report

\begin{tabular}{|c|c|c|c|c|}
\hline Researchers & Research Method & Main Results/ Findings & $\begin{array}{l}\text { Does KAM Increase } \\
\text { Communicative } \\
\text { Value? }\end{array}$ & Main Limitations \\
\hline
\end{tabular}

\section{Research Carried Out Using Data Obtained and/or Conducted Before Implementation of KAM Standard (Pre-Implementation)}

\section{Measuring Perception}

Simnet and The research analyzed 165 stakeholders'

Huggins (2014) responses to the IAASB's 2012 Invitation to Comment: Improving the Auditor's Report (ITC).

1) Most stakeholders $(62.3 \%)$ believed that the disclosure of key audit matters (KAM) provided the information needed by report users related to the entity through audit reports.

2) Groups of financial statement users (investors, bankers, and analysts) considered that the KAM concept could minimize the information gap in the auditor's report.

Litjens et al. (2015)

Boolaky Quick (2016)

and It was a case study of 105 directors of banks in Germany in the case of credit applications for beverage manufacturers listed on the German Stock Exchange.
1) The audit expectation gap (AEG) of bankers can be reduced by providing information about audit procedures related to the company's going concern and by disclosing errors found by the auditor in the financial statements.

2) As users of audit reports, bankers view that any additional pieces of information provided by the auditor are important. This was true, especially those related to the important. This was true, especially those related to the
entity (violations of covenants, internal controls, and regarding the company's going concern and materiality used).

Disclosure of KAM did not affect the perception of bank directors in studying the financial statements and the quality of the audit, or the value of the information contained in the audit report. Disclosure of KAM also did not affect the decision of the bank directors to grant/approve credit to the entity. accounting policies) and the audit process (audit procedures
Yes

There was a bias effect of the 1 to 5 coding schemes, which the researcher constructed to quantify the response to the ITC.

1) AEG measurement is subjective because it is assessed using a 1 to 6 perception scale.

2) The study was conducted on small and medium-sized companies in the Netherlands (SME). Also, users of financial statements used as research subjects were only bankers operating in the SME market. Thus, the results of the study cannot be generalized to other research contexts.

KAM used in the research did not match the definition of KAM in the Exposure Draft (ED) ISA 701. It was related to uncertainty and risk. The effect of disclosing KAM according to that definition can cause risk perception for users and does not reflect the expansion/addition of information of auditor's report in general. 


\begin{tabular}{|c|c|}
\hline Researchers & Research Method \\
\hline $\begin{array}{l}\text { Prasad and } \\
\text { Chand (2017) }\end{array}$ & $\begin{array}{l}\text { They performed a content analysis of } 138 \\
\text { comment letters from respondent groups, } \\
\text { consisting of auditors, financial statement } \\
\text { preparers, and users of financial statements. } \\
\text { The participants originated from } 42 \text { countries } \\
\text { on the IAASB ED Reporting on Audited } \\
\text { Financial Statements: Proposed New and } \\
\text { Revised International Standards on Auditing } \\
\text { published in July 2013. }\end{array}$ \\
\hline
\end{tabular}

Main Results/ Findings

1) The majority of respondents $(80 \%)$, both respondent roup and country group, believed that the disclosure of KAM would increase the value of information on the audit. It can be achieved by increasing the level of awareness of users of the auditor's report on significant matters that come to the auditor's attention during the audit and by increasing users' understanding of audit procedures carried out by auditors.

2) $92 \%$ of auditor's report users (investors and analysts) supported and believed that KAM disclosure would provide relevant and useful information for their decision-making.

3) The study also revealed that the disclosure of KAM would lose its informational value when the KAM copied standard/boilerplate/template-based statements. In addition, the information value of KAM could be reduced or even lost if the disclosure of KAM was too long/much so that users could not understand the essence of KAM and the published audit opinion.

4) Most of the financial statement preparers (78\%) did not agree with the disclosure of KAM. The possible cause is their self-interest, such as a potential increase in audit fees and a possible increase in political risk for the entity being audited.

5) Most public accounting firms (80\%) supported and believed that KAM disclosure could increase the communicative value of the auditor's report.

Ozlanski (2019) The research was a case study of 148 nonprofessional investors with the criteria aged 18 years or over who bought shares within the last six months. The purchase of shares was not part of the obligations related to their work

The disclosure of critical audit matters (CAM) affected investors' decision-making only when appropriate financial statements disclosed as CAM. The existence of CAM disclosure reduced investors' perception of the credibility of financial reporting when the areas/elements in
Does KAM Increase

Communicative

\section{Main Limitations}

Value? accounting standards regulated the area/element in the the financial statements that were disclosed as CAM were regulated by appropriate accounting standards. The reason was that the emphasis on the existence of risk in financial statements through CAM disclosures was not congruent with the investors who expected that proper accounting standards could reduce financial reporting risk.
The determination of the elements included and excluded from the analysis of the comment letter was subjective based on the researcher's consideration.

2) Respondents' views cannot be generalized to reflect the views of the population.
1) Participants were non-professional investors, not a professional one.

2) In the study, only one type of CAM was shown. In practice, CAM disclosures can consist of several areas so that non-professional investors are unable to understand complex and technical CAM disclosures. 


\begin{tabular}{|c|c|c|}
\hline Researchers & Research Method & Main Results/ Findings \\
\hline $\begin{array}{l}\text { Kohler et al. } \\
(2020)\end{array}$ & $\begin{array}{l}\text { They conducted a case study with } 89 \\
\text { professional investors from Germany } \\
(82.28 \%) \text {; the US, the UK, or Canada } \\
(10.12 \%) \text {; and other countries in the world } \\
(7.60 \%) \text {. They also invited } 69 \text { non- } \\
\text { professional investors. The non-professional } \\
\text { investors were undergraduate and } \\
\text { postgraduate accounting students at well- } \\
\text { known German universities. }\end{array}$ & $\begin{array}{l}\text { 1) The disclosure of KAM with a negative tendency (in } \\
\text { research, KAM stating that small changes in key } \\
\text { assumptions can lead to impairment of goodwill) made } \\
\text { professional investors judge that the company's economic } \\
\text { condition was significantly better than companies whose } \\
\text { audit reports disclose KAM with a positive tendency (in } \\
\text { research, KAM stating that only large changes in key } \\
\text { assumptions can cause goodwill impairment). They } \\
\text { considered that companies whose audit reports revealed } \\
\text { KAM with negative tendencies were more } \\
\text { open/transparent, fairer, and more competent. Such } \\
\text { companies provided them with awareness of information } \\
\text { that they previously did not know so that they had more } \\
\text { trust in the company. } \\
\text { 2) Non-professional investors perceived that KAM did not } \\
\text { have communicative value for them. Such investors are } \\
\text { considered unable to understand the information contained } \\
\text { in KAM, which is very complex, coherent, and describes } \\
\text { real cases in the real world. }\end{array}$ \\
\hline
\end{tabular}

\section{Research Using Literature Review Method}

Bedard et al. This research employed a literature review

(2016) method by investigating 22 papers discussing key audit matters (including those that have not been published) from 2007 to mid-2015.

1) The disclosure of critical or key audit matters increases the value of the audit report for users. However, based on the perception of non-professional investors (accounting students), the disclosure of CAM/KAM made users tend to be less interested in investing their funds in the company because they assumed that additional disclosure indicated an increased risk of investing in the company.

2) KAM disclosure will provide the information needed by users in understanding the audited financial statements, such as information related to the client's main accounting policies, client business risks, and audit risk. Those can minimize the information gap related to the entity and the audits carried out
Does KAM Increase

Communicative

Main Limitations

Value?

Yes

1) The results of the study are not generalizable to other than the tested KAM.

2) The data used for the research was obtained in late 2013/early 2014, i.e. before disclosure of KAM was required. Meanwhile, in 2020, professional investors are more accustomed to reporting on KAM, and their reactions may be different.

The literature review method uses judgment so that it is subjective. 


\begin{tabular}{ll}
\hline Researchers & \multicolumn{1}{c}{ Research Method } \\
\hline $\begin{array}{l}\text { Measuring Perception } \\
\text { Segal (2019) }\end{array}$ & $\begin{array}{l}\text { The research interviewed } 20 \text { auditors } \\
\text { (director to partner level) from } 6 \text { audit firms } \\
\text { in South Africa. }\end{array}$ \\
Coram & $\begin{array}{l}\text { A case study involved 240 non-professional } \\
\text { report users in Australia as the participants. } \\
\text { 120 of them worked in accounting and } \\
\text { finance other than auditors, and the other }\end{array}$ \\
120 were undergraduate alumni.
\end{tabular}

Respondents considered that the disclosure of KAM would indeed provide additional information, but it would not necessarily increase the value of the information disclosed. Respondents argued that clients (audit committee and client directors) did not pay attention to KAM. Further, users who did not have adequate technical skills/expertise would find it difficult to understand KAM.

In general, KAM disclosure did not reduce the audit expectation gap (AEG) of report users. User perceptions regarding the responsibility and reliability of auditors (as AEG's proxy) were the same, regardless KAM was disclosed or not.

1) Investors believed that KAM disclosure increased the perceived value of the audit (perceived value) and auditor credibility (perceived credibility) compared to no KAM disclosure.

2) The increase in perceived value and perceived credibility through the disclosure of KAM was only felt when Non-big 4 audit firms carried out the audit. Meanwhile, when Big 4 audit firms carried out the audit, investors believed that the perceived value of the audit and the credibility of the auditors remained high, regardless KAM was disclosed or not.

1) KAM disclosure has relevant information that is useful

\section{Measuring Real Effect}

Junior and Galdi They employed the Event Study using the (2019) number of daily abnormal returns from each sample company on the days that are part of the information disclosure window. The sample covered companies listed on the Brazilian Stock Exchange consisting of 131 companies for 2015-2016 and 94 companies in 2017. for investors in the capital market to analyze and make investment decisions.

2) Variations in abnormal returns of stocks related to Standardized Financial Statements that have adopted KAM have a greater relationship than variations in abnormal returns from other information disclosed by companies in financial statements, either mandatory or voluntary.

\section{Does KAM Increase \\ Communicative \\ Main Limitations}

Value?
No

No

Yes
1) The screening of interview results was subjective. Besides, the number of respondents was relatively small, so that the results cannot be generalized.

2) The research did not conduct interviews with other stakeholders such as regulators, analysts, and audit committees. investors.

2) It was only presenting one KAM per audit report, although KPMG (2017) highlighted that the average KAM in Australia is 2.8 .

1) The research used the perception of non-professional investors (master students in accounting).

2) The conclusions cannot be generalized to companies outside the tested industry (large public companies).

There might be other uncontrolled effects that affect stock price volatility and daily stock returns. 


\begin{tabular}{|c|c|c|c|c|}
\hline Researchers & Research Method & Main Results/ Findings & $\begin{array}{l}\text { Does KAM Increase } \\
\text { Communicative } \\
\text { Value? }\end{array}$ & Main Limitations \\
\hline $\begin{array}{l}\text { Kitiwong and } \\
\text { Sarapaivanich } \\
(2020)\end{array}$ & $\begin{array}{l}\text { The study used logistic regression with a } \\
\text { sample of } 1,519 \text { firm-year observations } \\
\text { obtained from } 312 \text { companies in Thailand } \\
\text { from 2014-2018 ( } 2 \text { years before and } 2 \text { year } \\
\text { after the implementation of ISA } 701 \text { in } \\
\text { Thailand/2016). }\end{array}$ & $\begin{array}{l}\text { 1) The disclosure of KAM made audit reports more } \\
\text { informative, especially those in connection with } \\
\text { acquisitions which indicated a potential restatement of } \\
\text { financial statements in the following year. } \\
\text { 2) KAM disclosures that were too general and using the } \\
\text { same/repeated/standard or boilerplate statements could } \\
\text { make audit reports less informative. KAM disclosures } \\
\text { should be specific to each audit engagement, even within } \\
\text { the same industry. }\end{array}$ & Yes & $\begin{array}{l}\text { Observations were only made on the } \\
\text { restatement of financial statements for } \\
2 \text { years after the implementation of } \\
\text { ISA } 701 \text { in } 2016 \text { ( } 2017 \text { and 2018). } \\
\text { Hence, the impact of KAM } \\
\text { disclosure on the restatement was not } \\
\text { yet clear. }\end{array}$ \\
\hline \multicolumn{5}{|c|}{ Research Using Literature Review Method } \\
\hline $\begin{array}{l}\text { Velte and Issa } \\
\text { (2019) }\end{array}$ & $\begin{array}{l}\text { The study reviewed } 49 \text { empirical studies } \\
\text { (journals, working papers, dissertations). }\end{array}$ & $\begin{array}{l}\text { The added value of KAM disclosure is still controversial } \\
\text { because various studies provide different conclusions. } \\
\text { Although there are indications that there is a decrease in } \\
\text { earnings management behavior, most studies found that } \\
\text { there is no significant change in audit behavior. In addition, } \\
\text { many studies have yielded insignificant results regarding } \\
\text { the benefits of KAM for stakeholders. }\end{array}$ & No & $\begin{array}{l}\text { The study did not mention the } \\
\text { limitations of the research. }\end{array}$ \\
\hline
\end{tabular}




\section{Does the Disclosure of Key Audit Matters Increase the Communicative Value of the Auditor's Report?}

Based on the time of data collection and/or the time of conducting the researchs, research articles that examine the impact of key audit matters (KAM) disclosure on the communicative value of the auditor's report can be divided into two groups. The first group is those that examine KAM disclosure before the implementation of KAM standard/pre-implementation (Simnet and Huggins 2014; Litjens et al. 2015; Bedard et al. 2016; Boolaky and Quick 2016; Prasad and Chand 2017; Ozlanski 2019; Kohler et al. 2020). Meanwhile, the other group is articles that examine KAM disclosure after the implementation of KAM standard/post-implementation (Junior and Galdi 2019; Segal 2019; Velte and Issa 2019; Coram and Wang 2020; Kitiwong and Sarapaivanich 2020; Moroney et al. 2020). As presented in Table 2, approximately $69 \%$ of the articles (9 out of 13 articles), i.e. pre-implementation articles (Simnet and Huggins 2014; Litjens et al. 2015; Bedard et al. 2016; Prasad and Chand 2017; Ozlanski 2019; Kohler et al. 2020) and post-implementation articles (Junior and Galdi 2019; Kitiwong and Sarapaivanich 2020; Moroney et al. 2020) found that KAM disclosure increases the communicative value of the auditor's report that is useful for report users in consideration for their decision making.

Most of the aforementioned articles that measured perceptions, both preimplementation and post-implementation articles, figured out that KAM disclosures provided useful information for users of auditor reports in decision-making. The users include professional investors (Simnet and Huggins 2014; Prasad and Chand 2017; and Kohler et al. 2020), analysts (Simnet and Huggins 2014; Prasad and Chand 2017), lenders/bankers (Simnet and Huggins 2014 and Litjens et al. 2015), and non-professional investors (Ozlanski 2019; Moroney et al. 2020). Regarding the real impact of KAM disclosure, Junior and Galdi (2019) found that KAM disclosure has relevant information that is useful for investors in the capital market to analyze investment decisions. In addition, Kitiwong and Sarapaivanich (2020) argued that KAM disclosure makes the auditor's report more informative, especially related to acquisitions, as the disclosure indicates a restatement of financial statements in the next periods.

Therefore, the result of this paper supports the implementation plan of AS 701 in Indonesia for audits of financial statements that financial year starting on or after January 1 2022, for listed entities on the Indonesia Stock Exchange as proposed in DE AS 701 because the disclosure of KAM will able to increase the communicative value of the auditor's report. However, it is also necessary to consider the risk of KAM disclosure. Knechel et al. (2016) found a risk that non-standard audit opinions, such as KAM disclosure, could affect the relationship between the auditor and the client. Therefore, it potentially leads the client to no longer use the auditor in the following year's audit engagement.

However, several studies (Boolaky and Quick 2016; Segal 2019; Velte and Issa 2019; Coram and Wang 2020) that measure perceptions did not advocate the disclosure of KAM. They doubt if the disclosure will increase the communicative value of the auditor's report. Pre-implementation research conducted by Boolaky and Quick (2016) found that KAM disclosure did not increase the information value contained in the auditor's report because it did not influence the decision of bank directors in providing credit to companies. However, Boolaky and Quick (2016) emphasized that their research did not use KAM according to the definition in ED ISA 701 but use artificial KAM related to uncertainty and risk. Hence, it cannot reflect the impact of KAM disclosure as referred to in ISA 701.

Furthermore, post-implementation research conducted by Segal (2019) interviewed 20 auditors found that the disclosure of KAM did not necessarily increase the value of the information disclosed. The study revealed that the audit committee and 
Table 3.

\section{Specific Areas often Disclosed as KAM}

\begin{tabular}{ll}
\hline Researchers & Specific Areas disclosed as KAM \\
\hline Litjens et al. (2015) & $\begin{array}{l}\text { Information about audit procedures related to the going concern of the } \\
\text { entity; materiality used by the auditor; the disclosure of errors found by } \\
\text { the auditor in the financial statements; entity-specific information in the } \\
\text { form of covenant violations, entity internal control, and entity account- } \\
\text { ing policies. }\end{array}$ \\
$\begin{array}{l}\text { Bedard et al. (2016) } \\
\text { Kitiwong dan } \\
\text { Sarapaivanich (2020) }\end{array}$ & \begin{tabular}{l} 
Information regarding acquisitions by the entity. \\
\hline
\end{tabular}
\end{tabular}

client directors did not pay special attention to KAM and might not understand KAM disclosure because it requires high technical ability/knowledge from report users (Segal 2019). However, Segal (2019) underlined that his research used relatively few participants and did not conduct interviews with other stakeholders such as regulators, analysts, and audit committees. On the contrary, Prasad and Chand (2017), based on the analysis of Comment Letters on the IAASB Exposure Draft (ED) ISA 701 , reported that most public accounting firms $(80 \%)$ supported and believed that KAM disclosure would increase the communicative value of the auditor's report.

Post-implementation research by Coram and Wang (2020), using a case study of non-professional report users in Australia, noted that KAM disclosure did not reduce the audit expectation gap (AEG) of them. However, they also underlined that their research only involved nonprofessional investors and only used one KAM, even though the average KAM in Australia was about 3. Otherwise, Kohler et al. (2020) found that non-professional investors could not fully understand the information contained in KAM because it is very complex, technical, and describes real cases in the real world.

Another study conducted by Velte and Issa (2019) doubted that the disclosure of KAM could increase the communicative value of the auditor's report. The reason is that various studies related to the benefits of KAM disclosure provide different re- sults/findings (Velte and Issa 2019). However, it has not included a number of studies used in this study, both those measuring perceptions (Litjens et al. 2015; Ozlanski 2019; Segal 2019; Kohler et al. 2020; \& Moroney et al. 2020) and those measuring real effects for the disclosure of KAM (Junior and Galdi 2019; Kitiwong and Sarapaivanich 2020). Meanwhile, among these studies, most of them (Litjens et al. 2015; Ozlanski 2019; Kohler et al. 2020; Moroney et al. 2020; Junior and Galdi 2019; and Kitiwong and Sarapaivanich 2020) found that the disclosure of KAM could increase the communicative value of the auditor's report.

\section{What Considerations Should Be Taken into Account Related to Disclosure of Key Audit Matters? \\ Specific Areas often Disclosed as KAM}

Litjens et al. (2015) revealed that any additional information disclosed by the auditor as KAM is important information for report users. Specifically, Litjens et al. (2015) identified several areas that are frequently disclosed as KAM. These areas are important to users, including information about audit procedures related to the going concern of the entity; materiality used by the auditor; disclosure of errors found by the auditor in the financial statements, entity-specific information in the form of covenant violations, entity internal control, and entity accounting policies. Furthermore, Bedard et al. (2016) found that the disclosure of KAM related to the entity's main accounting policies, the 
Table 4.

Factors that Can Decrease Communicative Value of KAM Disclosure

\begin{tabular}{ll}
\hline Researchers & $\begin{array}{l}\text { Conditions that Can Decrease Communicative Value of KAM Dis- } \\
\text { closure }\end{array}$ \\
\hline $\begin{array}{l}\text { Prasad and Chand (2017); } \\
\begin{array}{l}\text { Kitiwong dan } \\
\text { Sarapaivanich (2020) }\end{array}\end{array}$ & $\begin{array}{l}\text { KAM is disclosed in standard boilerplate statements or templates over } \\
\text { time. }\end{array}$ \\
$\begin{array}{l}\text { Prasad and Chand (2017) } \\
\text { KAM disclosure is too long/much (auditor report being more than three } \\
\text { pages). }\end{array}$ \\
$\begin{array}{l}\text { Kitiwong dan } \\
\text { Karapaivanich (2020) }\end{array}$ & $\begin{array}{l}\text { KAM disclosures are too general and do not adjust to the specific condi- } \\
\text { tions of the audited entity. }\end{array}$ \\
\hline
\end{tabular}

entity's business risk, and audit risk can reduce the information gap regarding the entity and the audits carried out. Meanwhile, Kitiwong and Sarapaivanich (2020) reported that the disclosure of KAM related to acquisitions is important information for users because it indicates a restatement of financial statements in the next period. The specific areas that are often disclosed as KAM are listed in Table 3.

In addition, Kohler et al. (2020) found that disclosure of KAM would increase professional investor confidence even though in a negative tendency (such as the statement in which small changes in key assumptions can cause goodwill impairment). Such disclosure implied that the company's economic condition is better than companies that disclose KAM with a positive tendency (such as the statement that only major changes in key assumptions can cause an impairment of goodwill). The reason is investors perceive that companies disclosing KAM with negative tendencies are more transparent, fairer, and more competent (Kohler et al. 2020). Furthermore, Kohler et al. (2020) emphasized that financial statement preparers, audit committees, and auditors should not be afraid of disclosing KAM with a negative tendency because it could make users perceive that the auditor's report is more reliable. Further, investors see the company's economic condition better than companies whose audit reports disclose KAM with a solely positive tendency.

As additional information, Moroney et al. (2020) found that the communicative value of auditor's report for nonprofessional investors only occurred when the audit was carried out by Non-big 4 audit firms. The communicative value was manifested in the form of an increase in the perceived value of the audit and the auditor's perceived credibility. Meanwhile, they stated that when the Big 4 audit firms carried out the audit, the perceived value of the audit and the credibility of the auditor remained the same whether KAM was disclosed or not. However, Moroney et al. (2020) stated that their research only used non-professional investors, namely students taking master's degrees in accounting. As a result, it cannot be generalized to professional investors. Contrary to that, according to Kohler et al. (2020), nonprofessional investors (such as students) cannot fully understand the information contained in KAM because it is very complex, technical, and describes real cases in the real world. Therefore, from the professional investor's point of view, it can't be fully believed that the communicative value of the auditor's report by the Big 4 audit firms is at the same level whether there is KAM disclosure or not.

\section{Factors that Can Decrease Communicative Value of KAM Disclosure}

According to some scholars (Prasad and Chand 2017; Kitiwong and Sarapaivanich 2020), several factors need to be considered regarding conditions that can decrease the communicative value of KAM disclosure, as presented in Table 4. 
Several studies give special attention to the conditions that can decrease or even eliminate the communicative value of KAM disclosure in auditor reports. Prasad and Chand (2017) and Kitiwong and Sarapaivanich (2020) found that the communicative value of KAM disclosures can be reduced or even lost if KAM disclosure is stated in standard boilerplate statements or templates over time. Such statements make the disclosure of KAM unable to provide specific information on the main areas requiring special attention from report users. As mentioned in ISA 701, the KAM disclosure should vary between entities and industries. Prasad and Chand (2017) claimed that the communicative value of KAM disclosure could also be reduced if KAM disclosure is too long/much. It makes users not understand the essence of KAM and the published audit opinion. ICAA (2013), as cited in Prasad and Chand (2017), claimed that KAM disclosure that contain more than three pages have the potential to obscure important information in the auditor's report for users. In addition, Kitiwong and Sarapaivanich (2020) emphasized that KAM disclosure should be specific to each audited entity even in the same industry because KAM disclosure that is too general can reduce the communicative value of the auditor's report. However, these matters have been arranged in the ED AS 701 issued by IAPI.

\section{CONCLUSION}

This research conducted a systematic literature review of the latest articles from 2012 to 2021 regarding the impact of disclosing key audit matters on the communicative value of an auditor's report. The study revealed two main results. First, the disclosure of key audit matters (KAM) increases the communicative value of the auditor's report, which is useful for report users as a consideration in making decisions. This is in line with the objectives of KAM as stated in ISA 701. The disclosure of KAM in the auditor's report can reduce the information gap for report users by providing previously unavailable information regarding the entity and the audit performed. However, KAM disclosure also potentially affects the auditor's relationship with the client because the disclosure is reported to trigger the client to no longer use the auditor in the next audit engagement.

Second, several factors need to be considered concerning the disclosure of key audit matters. The first factor covers specific areas that are frequently disclosed as KAM namely information about audit procedures related to the going concern of the entity; materiality used by the auditor, the disclosure of errors found by the auditor in the financial statements; entity-specific information in the form of covenant violations, entity internal control, and entity accounting policies. Additionally, the areas include the entity's business risks, audit risk, and information related to acquisitions made by the entity. The second factor is the attempts not to decrease the communicative value of KAM disclosure. To do so, several issues must be considered. First, KAM should not be disclosed in standard boilerplate statements or templates over time. Instead, it should be adjusted to the specific conditions of the entity being audited. Second, the disclosure of KAM should not be too long/much because it makes report users unable to understand the essence of KAM and the published audit opinion. Third, KAM disclosure should not be too general, but they should be specified following the conditions of the entity being audited. As for that substance, these three issues have been regulated in ED AS 701.

This research gives contributions in several aspects. First, this study provides additional information on the benefits of KAM disclosure for users of auditor reports. Therefore, the results of this study give additional information that provides support for the implementation plan of AS 701 in Indonesia for audits of financial statements that financial year starting on or after January 1 2022, for listed entities as proposed in ED AS 701. Second, this 
research provides initial knowledge for auditors in preparing AS 701 implementation regarding specific areas that are often disclosed as KAM and factors that can reduce the communicative value of KAM disclosure in producing information that is useful for report users. Third, this study provides information for users of the auditor's report on matters related to KAM disclosure. Fourth, this research is expected to provide initial information regarding KAM disclosure for regulators in Indonesia. Hence, they might find the information useful for their duties when AS 701 has been effectively implemented.

Nevertheless, this study has limitation namely researchers' subjectivity is possible in extracting and interpreting the information in the articles reviewed. Although we have made repeated checks for the information extracted from the article by looking at the suitability of the research results/findings with the research questions, alignment with the research conclusions, and conformity with the abstracts, the risk of subjectivity remains existed. In addition, further research can also be directed to include interviews with stakeholders related to ED AS 701 in Indonesia, including report users (such as investors, analysts, lenders), auditors, financial statement preparers, and regulators.

\section{REFERENCES}

Auditing and Assurance Standards Council. 2017. Questions and answers (Q\&A) on the new auditor's report. Philippines.

Accounting and Coporate Regulatory Authority, Association of Chartered Certified Accountants, Institute of Singapore Chartered Accountants, \& Nanyang Technological University. 2017. Embracing transparancy, enhancing value: $A$ first year review of the enhanced auditor's report in Singapore. Singapore.
Bedard, J. et al. 2016. Does recent academic research support changes to audit reporting standards?. Accounting Horizons, 30 (2), 255275.

Boolaky, P. K. and R. Quick. 2016. Bank directors' perceptions of expanded auditor's reports. International Journal of Auditing, 20, 158-174.

Browning, M. E. M. and A. Rigolon. 2019. School green space and its impact on academic performance. International Journal of Environmental Research and Public Health, 16 (3), $1-22$.

Coram, P. J. and L. Wang. 2020. The effect of disclosing key audit matters and accounting standard precision on the audit expectation gap. International Journal of Auditing, 1-13.

Ginieis, M., M. V. Sanchez-Rebull., and F. Campa-Planas. 2012. The academic journal literature on air transport: Analysis using systematic literature review methodology. Journal of Air Transport Management, 19, 31-35.

International Auditing and Assurance Standard Board. 2012. Invitation to comment: Improving the auditor's report. New York.

International Auditing and Assurance Standard Board. 2013. Exposure draft Reporting on audited financial statements: Proposed new and revised international standards on auditing (ISAs). New York.

International Auditing and Assurance Standard Board. 2015a. International standard on auditing 701: Communicating key audit matters in the independent auditor's report. New York.

International Auditing and Assurance Standard Board. 2015b. The new auditor's report: Greater transparency into the financial statement audit. New York. 
Institut Akuntan Publik Indonesia. 2021. Draf Eksposur Standar Audit 701: Pengomunikasian hal audit utama dalam laporan auditor independen. South Jakarta.

Jean-Francois, G., R. Laetitia, and D. Stefan. 2013. Is the coverage of google scholar enough to be used alone for systematic reviews. BMC Medical Informatics and Decision Making, 13 (7), 1-5.

Junior, E. D. A., and F. C. Galdi. 2019. The informational relevance of key audit matters. Revista Contabilidade $e$ Financas, 31 (82), 67-83.

Kend, M., and L. A. Nguyen. 2020. Investigating recent audit reform in the Austalian context: An analysis of the KAM disclosures in audit reports 2017-2018. International Journal of Auditing. 24, 412-430.

Kitiwong, W., and N. Sarapaivanich. 2020. Consequences of the implementation of expanded audit reports with key audit matters (KAMs) on audit quality. Managerial Auditing Journal, 35 (8), 1095-1119.

Knechel, W.R. et al. 2016. Brain Drain or Survival of the Fittest: Determinants and Consequences of Auditors' Leaving Public Accounting.

Kohler, A., N. Ratzinger-Sakel, and J. Theis. 2020. The effect of key audit matters on the auditor's report's communicative value: Experimental evidence from investment professionals and non-professional investors. Accounting in Europe, 17 (2), 105-128.

Litjens, R., Buuren, J., and Vergoosen, R. 2015. Addressing information needs to reduce the audit expectation gap: Evidence from dutch bankers, audited companies and auditors. International Journal of Auditing, 19, 267-281.
Martin-Martin, A., E. Orduna-Malea, A. Harzing, and E. D. Loper-Cozar. 2017. Can we use Google Scholar to identify highly-cited documents? Journal of Infometrics, 11 (1), 152163.

Min, L. M. and P. L. Kee. 2019. Disclosures of key audit matters to curb information asymmetry. International Journal of Accounting, Finance and Business, 4 (24), 1-12.

Moroney, R., S. Phang, and X. Xiao. 2020. When do investors value key audit matters? European Accounting Review. 30 (1), 63-82.

Ozlanski, M. E. 2019. Bright lines vs blurred lines: When do critical audit matters influence investor's perceptions of management's reporting credibility?. Advances in Accounting, 45 (3), 1-11.

Prasad, P. and P. Chand. 2017. The changing face of the auditor's report: Implications for suppliers and users of financial statements. Australian Accounting Review, 27 (4), 348-367.

Sanchis, M. N. et al. 2014. The role of central sensitization in shoulder pain: a systematic literature review. Seminars in Arthritis and Rheumatism, 44 (6), 710-716.

Segal, M. 2019. Key audit matters: Insight from audit experts. Meditary Accountancy Research, 27 (3), 472494.

Simnet, R. and A. Huggins. 2014. Enhancing the auditor's report: To what extent is there support for the IAASB's proposed changes? Accounting Horizons, 28 (4), 719-747.

Snyder, H. 2019. Literature review as a research methodology: An overview and guidelines. Journal of Business Research, 104, 333-339.

Tranfield, D., D. Denyer, and P. Smart. 2003. Towards a methodology for developing evidence-informed 
management knowledge by means of systematic review. British Journal of Management, 14, 207-222.

Velte, P., and J. Issa. 2019. The impact of key audit matters (KAM) disclosure in audit reports on stakeholders' reactions: A literature review. Business Perspectives, 17 (3), 323-341.

Wu, X., Y. Fan, and Y. Yang. 2019. Do critical audit matters signal higher quality of audited financial information? Evidence form asset impairment. China Journal of Accounting Studies, 7 (2), 170-183. 